\title{
VALUE CHAIN PALM OIL INDUSTRY ANALYSIS ON THE POLYOL POLYESTER PATHWAY
}

\author{
Adriana Sari Aryani ${ }^{1}$, Yulian Syahputri ${ }^{2}$, Hermawan $^{3}$ \\ ${ }^{1,3}$ Department of Computer Science, Universitas Pakuan Bogor \\ ${ }^{2}$ Departement of Chemistry,Universitas Pakuan Bogor \\ 19adriana.aryani@gmail.com, ${ }^{2}$ yulian.syahputri@gmail.com, ${ }^{3}$ hermawan.taher@unpak.ac.id
}

\begin{abstract}
Palm oil is one of important Indonesia's export commodities. In 2017, the export value of palm oil and its derivatives (excluding oleochemicals and biodiesel) penetrated US \$ 22.97 billion. The bright prospect of the palm oil commodity in the world vegetable oil trade encouraged the Indonesian government to develop an integrated palm oil industry. On the other hand, some downstream petrochemical products have begun to experience difficulties in raw materials, including Polyurethane. Polyurethane is a polymeric material from polyols and isocyanates which are widely used as packaging. Polyol itself is a polyether produced from the petroleum fraction. The polyol industry can be developed in the industrial tree branch of glycerol / glycerin in the large palm oil industry tree. Glycerin is generally the most end product of the palm oil fractionation industry, after cooking oil, margarine, shortening, and soap. In addition, glycerin is also a by-product of fatty acid esterification during biodiesel production. The value chain analysis carried out in the palm oil industry chain shows that polyol production has added new pathways that can extend the palm oil downstream industry chain. Analysis carried out on the main chain and the combined oil palm industry chain has been successfully used to map the polyol industry value chain on the palm oil track. The extension of the palm oil industry value chain on the polyol industry pathway can unite the industry with the chain of production of the petrochemical industry, in this case polyurethane, which at least can help substitute raw materials. A more detailed analysis of the perceptions of the role of the polyol industry in two directions, namely the palm oil industry chain with the polyurethane industry shows that there is a very large intersection of interests. Almost all perceptions of the role of key value chain activities in the polyurethane industry can be covered by the role of the value chain main activities in the palm oil polyol industry. Both value chains can be said to complement and complement each other. The production of polyester polyols can be absorbed by the needs of the polyurethane industry.
\end{abstract}

Keywords : Value Chain Analysis, Palm Oil Industry, Polyesther Polyol, Poly Urethane

\section{INTRODUCTION}

Oil palm is one of the plantation commodities which has an important role in economic activities in Indonesia. Oil palm is also one of Indonesia's export commodities which is quite important as a foreign exchange earner besides oil and gas. In 2017, the export value of palm oil and its derivatives (excluding oleochemicals and biodiesel) reached US $\$ 22.97$ billion, up 26 percent compared to 2016 which only reached US $\$ 18.22$ billion. The value of palm oil exports in 2017 is the highest value ever achieved in the history of Indonesian palm oil exports. The bright prospect of the palm oil commodity in the world vegetable oil trade has encouraged the Indonesian government to develop the palm oil industry in an integrated manner (agro-industry). 
The development of processing industries for palm oil derivative products has enormous benefits because it can provide greater added value. Palm oil can be processed into highervalue derivative products. Commercial products from palm oil derivatives in the world are already very much, the most popular being traded today is Crude Palm Oil (CPO) and derivatives of Edible Oil and margarine. The world market share of palm oil is $24.4 \%$ and the market share of soybean oil is $23.9 \%$ of the total consumption of world oil and fat as much as 143 million tons. The increase in demand for world palm oil is due to the increase in oil and fat consumption by 2-3 million tons per year in line with the increase in population and income levels of the world community.

The Government of Indonesia continues to strive to increase the economic added value of palm oil products, one of which is through the industry downstream program that has been characterized since 2015. The downstream oil palm industry program was developed through several channels such as food, agriculture, food, and oleochemistry. One of the undeveloped oleochemical products in Indonesia is polyester polyol.

Polyol is a raw material for the manufacture of polyurethane polymers which has a very large use in the world. Until now the need for polyols in Indonesia has continued to increase but has not been balanced by domestic production, because until now there has only been one domestic polyol producer, PT. Arco Chemical Indonesia, located in Ciwandan Serang, West Java, with a capacity of 26,000 tons per year (Gala, 2011). During this time polyols are produced from petroleum derivative products namely ethylene oxide and propylene oxide (Faleh, 2001).

The study of the Indonesian palm oil industry value chain analysis on polyester polyol lines is needed to support the supply chain of the downstream chemical industry. Some downstream chemical industries which have been using non-renewable sources of mineral, oil and natural gas raw materials are expected to be replaced with renerwable sources.

The scenarios needed for this industry value chain analysis study are prepared with several considerations including the position of the oleochemical industry as a prime remover for the sustainability of the downstream palm oil industry, oleochemical industry products as an alternative raw material for the downstream chemical industry, and availability of materials the standard of the domestic palm oil industry.

\section{PALM OIL DOWNSTREAM INDUSTRIES}

The world's market share of palm oil is $24.4 \%$ and the market share of soybean oil is $23.9 \%$ of total consumption of world oil and fat as much as 143 million tonnes. The increase in world palm oil demand occurred due to increased consumption of oil and fat amounting to 2-3 million tonnes per year with an increase in population and the income level of the world community. (Gapki, 2014)

The industry of Crude Palm Oil (CPO) is an industry that is built close to the presence of raw materials, namely oil palm plantations. A typical industry like this is typical for agricultural industry whose raw materials are quickly damaged (perishable) and kamba (bulky). By itself, the primary industries of palm oil processing are mostly built in Sumatra, Kalimantan, Sulawesi to Papua. The first derivative industry, which is a refinery that separates Olein and Stearin, is still possible to be built on the island of Sumatra, especially on the Malacca Strait trade route. Derivative commodities such as Olein, Stearin, and Palm Kernel Expeller have high export potential so that they are intentionally established on the path of international trade.

Palm oil derivative industries ranging from refinery, butter, soap, and other consumer goods, are typical industries that must be built close to the market. The largest market of the population is in Java, so the palm oil derivative industry for Consumer good is built on the island of Java. The map of the area for the distribution of the palm oil industry and its derivatives in Indonesia is presented in Figure 1. 

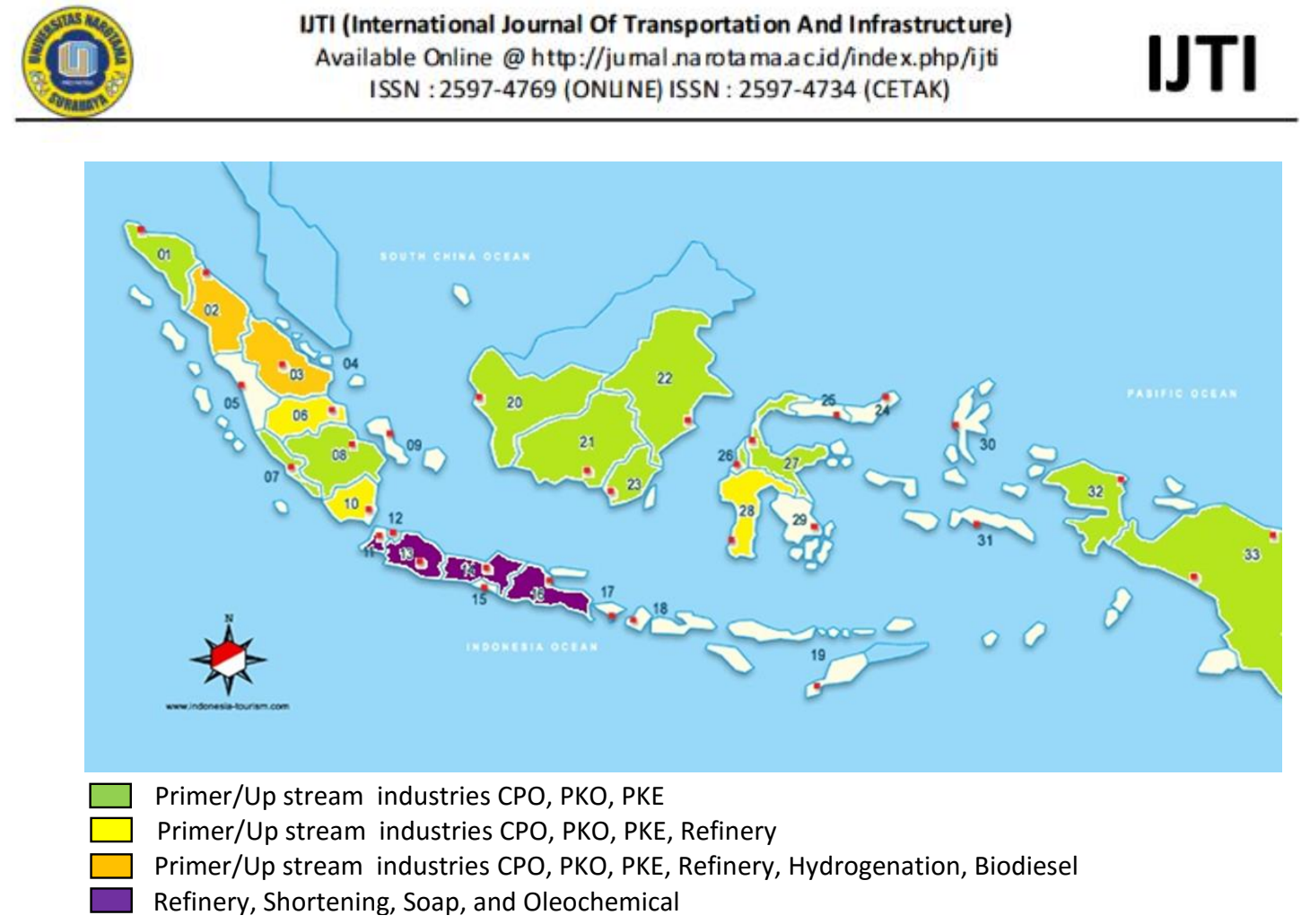

Figure 1. Distribution of the oil palm industry geographically in Indonesia

(Ministry of Industry, 2013)

Besides providing huge foreign exchange (above USD 17.9 billion in 2016), oil palm also provides employment for 3.5 million farmers, or equivalent to a minimum of around 14 million Indonesians who depend on oil palm. The world demand for palm oil is expected to continue to increase considering palm oil is quite applicable in various fields, including its use as a raw material for oleochemicals. Thus, the development of investment in the palm oil downstream industry in Indonesia will have a good market opportunity in the future.

Although the oleochemical potential is quite large, the oleochemical and biodiesel industry in Indonesia has not developed much compared to the refinery industry. One reason is that oleochemical plants require large technology and investment, infrastructure (electricity, roads, and ports) that has not been supported, and the temporary fact that the profits obtained in the upstream industry are greater. Table 1 shows the development of oleochemical production based on its type in Indonesia.

Table 1. Development of Oleochemical Production in Indonesia by the types

\begin{tabular}{|c|c|c|c|c|c|}
\hline \multirow{2}{*}{ Year } & \multicolumn{4}{|c|}{ Production (ton) } & \multirow{2}{*}{$\begin{array}{c}\text { Growth } \\
(\%)\end{array}$} \\
\hline & Fatty Acid & Fatty Alcohol & Glycerine & Total & \\
\hline 2006 & 504,309 & 208,395 & 96,746 & 809,450 & - \\
\hline 2007 & 412,401 & 273,659 & 134,918 & 820,978 & 1,42 \\
\hline 2008 & 479,012 & 300,612 & 157,351 & 936,974 & 14,13 \\
\hline 2009 & 498,951 & 331,943 & 144,158 & 975,052 & 4,06 \\
\hline 2010 & 632,871 & 336,414 & 185,818 & $1,55,052$ & 18,47 \\
\hline 2011 & 830,844 & 351,849 & 194,298 & $1,376,991$ & 19,27 \\
\hline & & Average Growth & & & 11,46 \\
\hline
\end{tabular}

Source: Gapki (2014) 
The Ministry of Industry (2015) noted that at least 40 groups of palm derivative products have been produced in Indonesia, 3 product groups are targeted to be produced until 2014 namely beta carotene, glycerol mono oleate, and food emulsifier, 8 product groups will be produced in the long term until 2025 , and there are still at least 18 product groups that have not been produced in Indonesia. Polyesther polyol is one of potential derivative product from Palm oil.

Research on the manufacture of polyester polyols has been reported by various researchers including Neny and Imron (2004) making polyols from Crude Palm Oil (CPO) by looking at the effect of reactant variables on epoxidation and hydroxylation reactions, the hydroxyl polyol numbers produced are still small and slightly cloudy, this is due CPO raw materials still contain impurities. Faleh and Zainal (2001) conducted a study of the hydroxylation process of palm oil into polyols against the formation of hydroxyl numbers.

\section{METHOD}

\section{Value Chain Analysis}

The relationship between the main industries and all related industries is the development of a value system concept developed by Porter. Every company is a set of activities carried out to design, produce, market, deliver and support its products. All of these activities can be described using the value chain.

Kaplinsky and Morris (2000) describe the vertical value chain as fields which are input or output of the industry. The vertical value chain is forward and backward. From the point of view of major industries, all vertically related industries are called "supporting industries". The concept was developed for the polyol industry from oil palm as shown in Figure 3.

The upstream chain is the downstream industry which is the main consumer of industrial products, in the case of the polyol industry, the polyurethane industry being its hirlir industry. Downstream chains are the upstream industry is a major industrial customer, in the case of the polyol industry, glycerol raw materials are obtained from the soap industry or from the biodiesel industry. Horizontal chains are other industries that are mutually supplying in their main chain, namely the palm oil industry. All industries involved in horizontal chains are called "related industries".

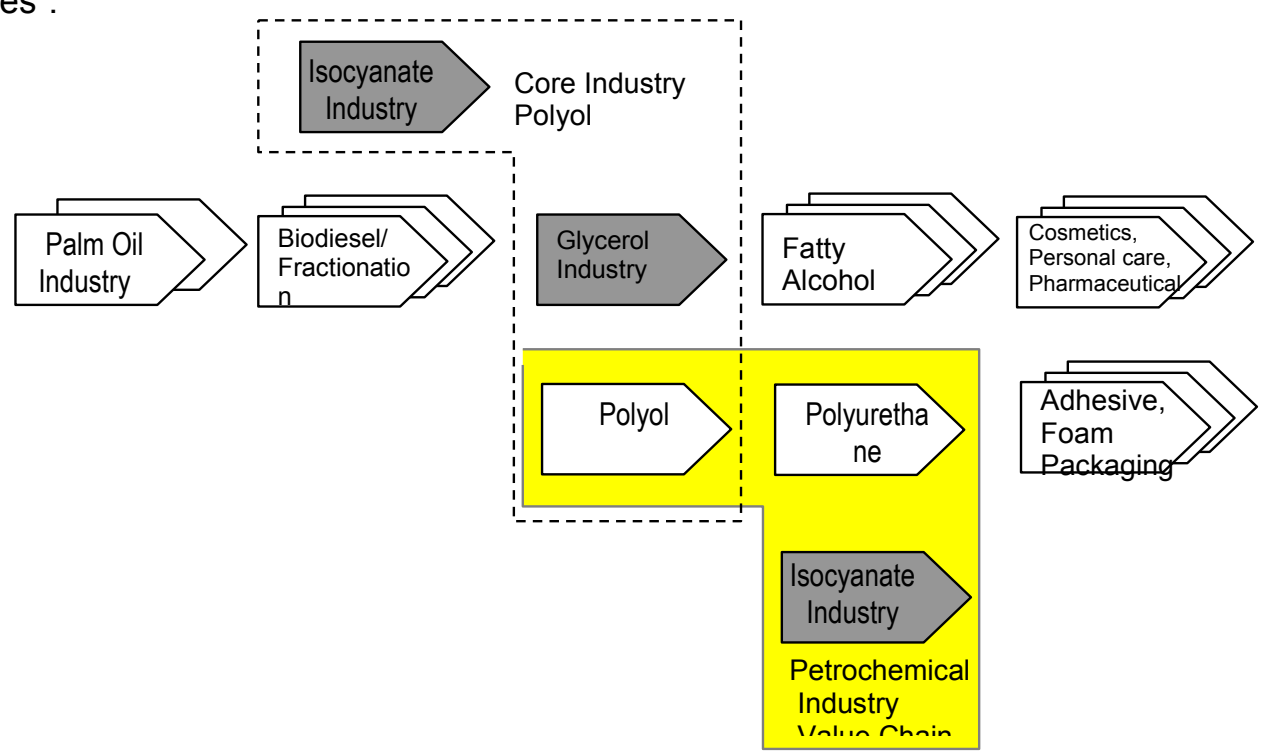

Figure 3. The Combination of Industrial Palm Oil and Petrochemical Value Systems 
The concept of value chains according to many experts is a powerful way to conceptualize business, where companies create value for product buyers with company activities. The value chain approach is based on a series of sequential activities, is a set of value activities carried out to design, produce, market, send and support their products and services.

The concept of value chains according to many experts is a powerful way to conceptualize business, where companies create value for product buyers with company activities. The value chain approach is based on a series of sequential activities, is a set of value activities carried out to design, produce, market, send and support their products and services.

Value chain analysis is useful as a framework for sorting / dividing companies into activities that aim to identify: 1) the size of the effect of the cost of an activity on total costs; 2) determinants of costs in each activity, effective and efficient in its activities; 3 ) the effect of the cost of an activity on other activities; and 4) sorting out activities carried out by the company and outsiders.

The company's value chain can also be used as a reference for reformulating the company's business, which according to Porter (1998) can be done in the following four ways.

a. Maintain business in key industries by strengthening existing corporate value chains.

b. Entering supporting industries based on the company's surplus chain.

c. Participate in the company's complementary chain by entering related industries.

d. Diversify unrelated outside existing industries to find more attractive and newer industries.

\section{Value Chain Construction}

Value chain construction is done through mapping the Perception index by paying attention to industrial distribution in the main chain (Mixed Chain) with its combined chain (Mixed Chain). The greater the downstream chain influence, the industry is far downstream (down stream) as well as the opposite. While the combined chain is to show the strength of the influence of other industries outside the main industry.

The value chain map uses downstream and upstream variables in the main chain representing the $X$ axis, as well as progressive and consolidative on the combined chain representing the $Y$ axis. However, the $X-Y$ combination is arranged based on expert perceptions.

\section{RESULTS AND DISCUSSION}

\section{Analysis of Downstream Industries and Palm Oil Industry Value Chains}

\section{Analysis of the Industrial Tree Scheme}

The basic oleochemical industry and Wrath is one of the priority upstream industries to be developed. In the National Plan of Industry Development (Ripin) 2015-2035, upstream agro industry will be developed among others is Oleofood industry, oleochemical and wrath. Oleofood industry that is focused to be developed or constructed until the year 2035 is Olein;Stearin; glycerol;Palm Fatty Acid Distillate(PFAD);Coco Butter Substitute; margarine;shortening;Other specialty Fats; Specialty fats (coco butter substitute); Tocopherols Betacaroten; Organic acids and alcohol from palm industrial waste and specialty fats food additives. The oleochemical industries that are focused to be developed or built up to the years 2035 include fatty acids, fatty alcohols, vegetable fatty acids (fatty amine), methyl estersulfonate ( Biosurfactant), biolubricant (rolling oils), glycerine based Chemical, isopropyl palmitate (IPP), isopropyl myristate (HDI), stearic acid ), Methyl esters, bioplastic (polybetahydroxybutirate/PHB, 
polyhydroxyvalerate/PHV, polylactate) based on Palm industrial waste; and polymerspalm oil derivatives.

Oleochemical is a chemical derived from the oil or fats through the process of splitting triglycerides (triacylglycerol) into the fatty acids and glycerol derivatives. The process can be done chemically and enzymatis. The oleochemical advantage of petrochemical is that oleochemistry is renewable, biodegradable, safer (not toxic). The more basic oleochemical produced include fatty acids, fatty alcohols, fatty methyl esters, fatty amines and glycerols. These basic oleochemical can be further processed into higher-value end products.

The industry tree is done through the glycerol products as the main source for the production of Polyol. The real glycerin product has grown in Indonesia, as the end product on fatty oil fractionation, the production of palm cooking oil. Some industries have even managed to reach the Pharmaceutical Grade. Glycerol is also a product of followings on Biodiesel plants, but still a few factories in Indonesia that build its integration.

\section{Value Chain Analysis}

To update The Association of industry in the value chain of the palm oil industry, identify perceptions of the two chains, namely the main Chain and the combined industrial chains (Mixed chain). The perception is assessed and formulated in table 2.

Table 2. Formulation of association in the value chain of the palm oil industry, Polyol subcluster

\begin{tabular}{|l|l|}
\multicolumn{1}{|c|}{ Up stream Industrial Support } & \multicolumn{1}{c|}{ Support to Down stream } \\
\hline Contributing to regional income & Dependence on Raw Materials \\
\hline Supported by Worker Skill & Technology Capabilities \\
\hline Productivity & Limited Market Access \\
\hline Market & Infratructure not ready yet \\
\hline Infrastructure Support & Instututional not support yet \\
\hline Political Policy & Human Resources Constraints \\
\hline Raw Materials Supply & Political Policy \\
\hline \multicolumn{1}{|c|}{ Developing Various Industry } & \multicolumn{1}{c|}{ Basic Industry Support } \\
\hline Value Added & Competition \\
\hline Labor & Political Policy Changes \\
\hline Multiplier Effect & Decreased supply of supporting materials \\
\hline Export oriented & Sustainability Aspects \\
\hline Opportunity to Expansion Scale Business & \\
\hline
\end{tabular}

Assessment of perception is done to a number of industries in the value chain as Figure 4, namely the industrial Crude Palm Oil, fractionation (cooking oil), Biodiesel, glycerol/glycerin, Poliol, and Fatty alcohol on the main chain of oil industry Oil palm. While the mixed chain is an isocyanate and polyurethane industry that currently uses petroleum (Petro Chemical) raw materials. The result of the perceptual assessment conducted by Expert against the four factors mapped in the value chain as shown in Figure 5. 


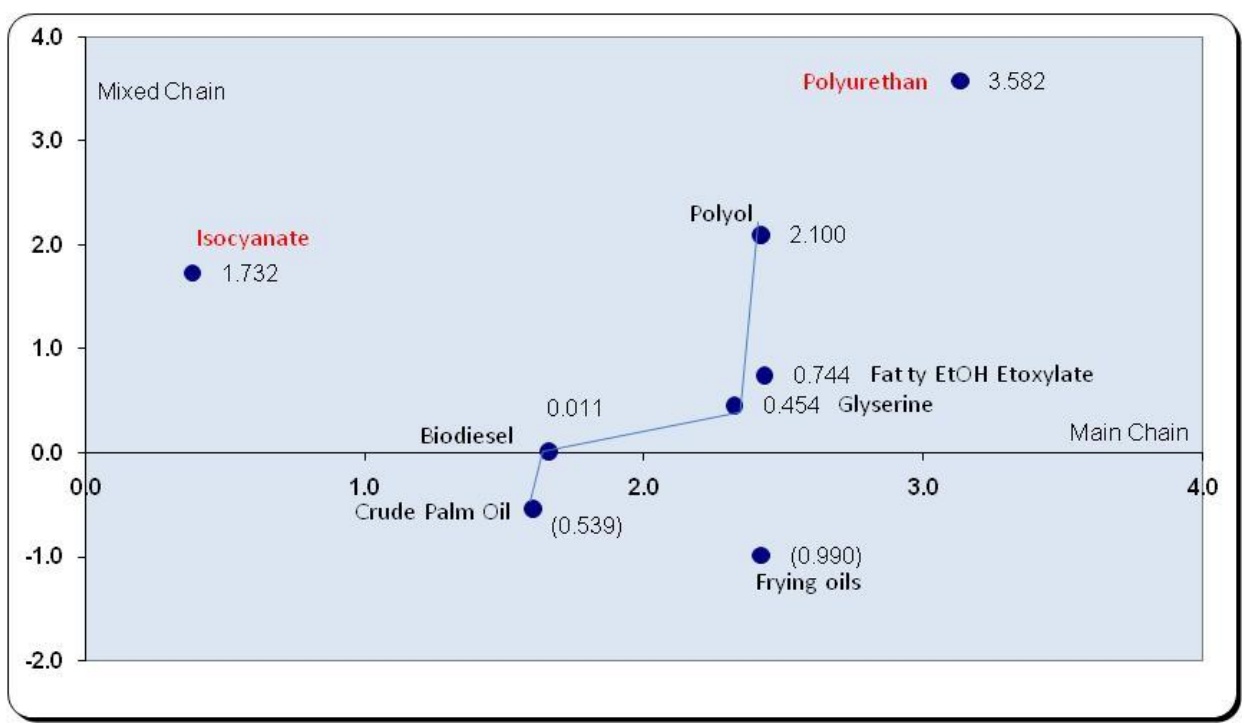

Fig. 5. Map of downstream oil palm industry value chain, polyol production line

Porter's value activities are abbreviated in two parts, namely primary activities and supportingactivities. Primary activities are activities involved in the creation of physical products and sales and transfer to buyers and after-sales assistance. While the supporting activities are primary supporting activities and support each other by providing the inputs purchased, technology, human Resources (SDM) and the basic institution of the company. A value chain application scheme that can be developed in the polyol industry is presented in Figure 6.

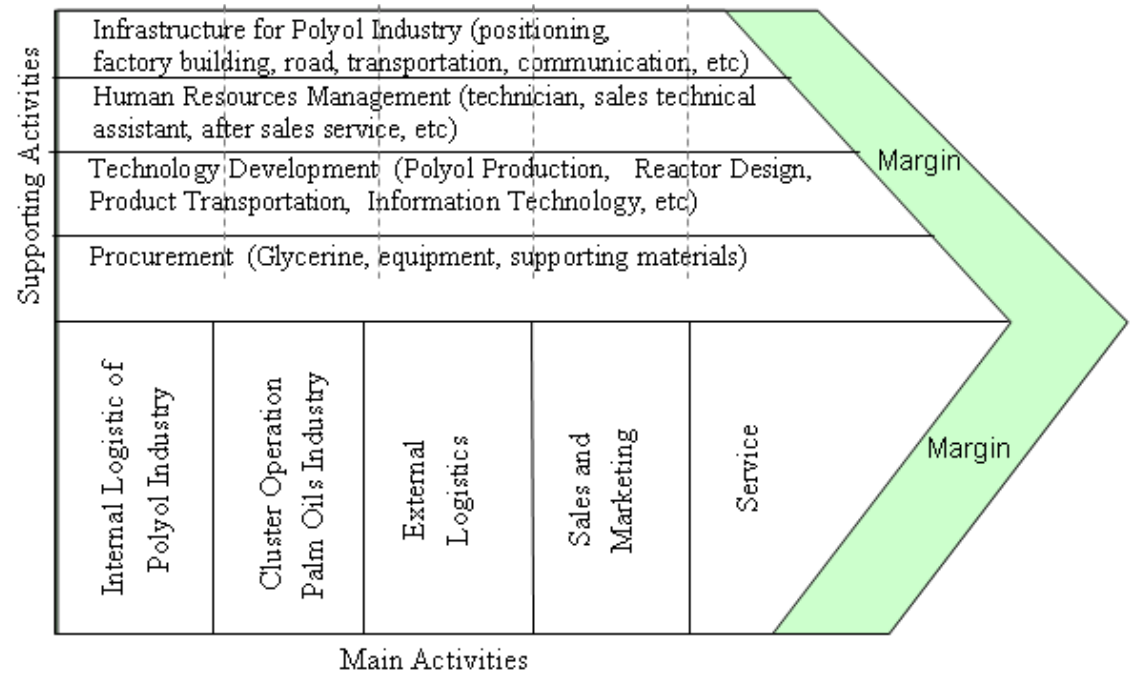

Figure 6. Industrial value chain of Poliol in palm industrial value chain

The relationship between the value chain and the capabilities of an industry, influenced by four important factors: 1) procurement capability; 2) technology and development; 3) Industrial Infrastructures; 4) Human Resources Development; and 5) Sustainability. Perception of fourfactor role is done to the main activity. Perception assessment is done with two perspectives: 
1. The perspective of the polyol industry of the palm oil industry's value chain

2. The perspective of the polyol industry of the polyurethane industrial value chain (petrochemical).

Both assessments are done separately in order for the assessment results to be more objective and do not influence each other. In the end, both judgments will be mapped together to find how large the closeness between the two actual value chains are.

The assessment is carried out against the main acity in the polyol chain of industrial chains of the industrial chain of palm oil. Perceptual perception is changed into fuzzy linguistic labels (Very Low-VL, Low-L, Medium-M, and High-H). The results are compiled in matrices,

A (1) $5 \mathrm{X} 4=$ Logistics to $=$ (material sourcing, warehousing, dosage control, transportation of purchases, return of defective products)

A $(2) 5 X 4=$ Operation $=$ (good production way, process control, quality control, research and development, cost control)

A (3) $4 \times 4=$ Logistics out $=$ (product warehousing, loading, transport delivery, product absorption) A $(4) 4 \times 4=$ Marketing and sales $=$ (sales promotion, customer handling, pricing policy, communication)

A (5) $2 X 4=$ Service $=($ After sale, training/technical assistant $)$

Next each matrix of assessment criteria is structured for alternative determination of choice. Assessment results of all activities influenced by all alternatives using formulations:

$$
\operatorname{VA}(1) f(A i)-\max [Q i b j]
$$

For the assessment of the polyol industry on the palm oil industry chain line is presented in Table 3 .

Table 3. Results of fuzzy linguistic label operations for assessment of the main activity of the industrial value chain of Poliol, from the perspective of the palm oil industry value chain

\begin{tabular}{|c|c|c|c|c|c|c|c|c|c|c|}
\hline \multirow{2}{*}{$\begin{array}{c}\text { Main } \\
\text { Activities }\end{array}$} & \multirow[b]{2}{*}{ Main Activities Delais } & \multicolumn{2}{|c|}{ Procurement } & \multirow{2}{*}{$\begin{array}{l}\text { Technology } \\
\text { Development }\end{array}$} & \multicolumn{2}{|c|}{ Infrastructure } & \multirow{2}{*}{$\begin{array}{l}\text { Human Ries } \\
\text { Development }\end{array}$} & \multicolumn{2}{|c|}{ Sustainability } & \multirow{3}{*}{ Aggregate } \\
\hline & & & & & & & & & & \\
\hline & & & $M$ & $M$ & & L & $\mathrm{VL}$ & & $\mathrm{H}$ & \\
\hline & Material Supply & 4.3089 & $\mathrm{H}$ & $2.2894 \mathrm{~L}$ & 1.2599 & $\mathrm{VL}$ & $1 \mathrm{VL}$ & 2.2894 & L & \\
\hline Internal & Warehousing & 3.3019 & $M$ & $2.6207 \mathrm{~L}$ & 1.2599 & $\mathrm{VL}$ & $1 \mathrm{VL}$ & 2.6207 & L & \\
\hline \multirow[t]{6}{*}{ Logistics } & Inventory Control & 3.6342 & $\mathrm{H}$ & $2.2894 \mathrm{~L}$ & & $\mathrm{VL}$ & $1 \mathrm{VL}$ & 2.6207 & L & \\
\hline & Purchase Transport & 3.3019 & $M$ & $2 L$ & & $\mathrm{VL}$ & $1 \mathrm{VL}$ & 2.2894 & L & \\
\hline & Retur & & $M$ & $2 \mathrm{~L}$ & & $\mathrm{VL}$ & $1 \mathrm{VL}$ & 1.2599 & L & \\
\hline & & & $M$ & $L$ & & $\mathrm{VL}$ & $\mathrm{VL}$ & & $\mathrm{L}$ & $M$ \\
\hline & Good Manufact.Practices & 3.3019 & $M$ & $3.1748 \mathrm{M}$ & 1.5874 & $\mathrm{VL}$ & $1.5874 \mathrm{VL}$ & 1.8171 & $\mathrm{VL}$ & \\
\hline & Process Control & & $M$ & $2.2894 \mathrm{~L}$ & 1.2599 & $\mathrm{VL}$ & $1.2599 \mathrm{VL}$ & 1.2599 & $\mathrm{VL}$ & \\
\hline Production & Quality Control & & $\mathrm{H}$ & $2 \mathrm{~L}$ & 1.2599 & $\mathrm{VL}$ & $1.5874 \mathrm{VL}$ & 1.4422 & $\mathrm{VL}$ & \\
\hline \multirow[t]{5}{*}{ Operation } & Research \& Development & 1.2599 & $\mathrm{VL}$ & $1 \mathrm{VL}$ & & $\mathrm{VL}$ & $1.2599 \mathrm{VL}$ & 1.2599 & $\mathrm{VL}$ & \\
\hline & Cost Control & 1.8171 & $\mathrm{VL}$ & $1 \mathrm{VL}$ & 1.2599 & $\mathrm{VL}$ & $1 \mathrm{VL}$ & & $\mathrm{VL}$ & \\
\hline & & & M & L & & $\mathrm{VL}$ & $\mathrm{VL}$ & & $\mathrm{VL}$ & $M$ \\
\hline & Product Warehousing & 3.3019 & $M$ & $2.8845 \mathrm{~L}$ & & $L$ & $1 \mathrm{VL}$ & & $\mathrm{VL}$ & \\
\hline & Stuffing & 2.2894 & L & $1.5874 \mathrm{VL}$ & 1.8171 & $\mathrm{VL}$ & $1 \mathrm{VL}$ & & $\mathrm{VL}$ & \\
\hline External & Transportation & 2.2894 & L & $2 \mathrm{~L}$ & 1.5874 & $\mathrm{ML}$ & $1 \mathrm{VL}$ & 1.2599 & $\mathrm{VL}$ & \\
\hline \multirow[t]{3}{*}{ Logistics } & Product Absoption & 2.2894 & L & $1 \mathrm{VL}$ & 1.2599 & $\mathrm{VL}$ & $1 \mathrm{VL}$ & 3.3019 & $M$ & \\
\hline & & & L & L & & $\mathrm{ML}$ & $\mathrm{VL}$ & & $\mathrm{VL}$ & $\mathrm{L}$ \\
\hline & Promotion/Advetisment & & $\mathrm{VL}$ & $3.6342 \mathrm{M}$ & & $\mathrm{VL}$ & $3 \mathrm{M}$ & & $\mathrm{VL}$ & \\
\hline Sales and & Customer Care & & $\mathrm{VL}$ & $3.3019 \mathrm{M}$ & & $\mathrm{VL}$ & \begin{tabular}{l|l}
$3.6342 \mathrm{M}$ \\
\end{tabular} & & $\mathrm{VL}$ & \\
\hline \multirow[t]{3}{*}{ Marketing } & Pricing policy & 1.2599 & $\mathrm{VL}$ & $1 \mathrm{VL}$ & & $\mathrm{VL}$ & \begin{tabular}{l|l}
2.6207 & $\mathrm{~L}$ \\
\end{tabular} & & $\mathrm{VL}$ & \\
\hline & Communication & & $\mathrm{VL}$ & \begin{tabular}{l|l}
$3.9149 \mathrm{M}$ \\
\end{tabular} & 2.6207 & L & $1.5874 \mathrm{VL}$ & & $\mathrm{VL}$ & \\
\hline & & & $\mathrm{VL}$ & \begin{tabular}{l|l}
$M$ \\
\end{tabular} & & $\mathrm{VL}$ & \begin{tabular}{l|l}
$M$ \\
\end{tabular} & & $\mathrm{VL}$ & $M$ \\
\hline \multirow[t]{3}{*}{ Services } & Aftersales service & 1.2599 & $\mathrm{VL}$ & $1 \mathrm{VL}$ & 2.2894 & $\mathrm{~L}$ & \begin{tabular}{l|l|}
4.6416 & $\mathrm{H}$ \\
\end{tabular} & & $\mathrm{VL}$ & \\
\hline & Training/Technical Assist & & $\mathrm{VL}$ & $1 \mathrm{VL}$ & & $\mathrm{VL}$ & $1 \mathrm{VL}$ & & $\mathrm{VL}$ & \\
\hline & & & $\mathrm{VL}$ & $\mathrm{VL}$ & & L & $\mathrm{VL}$ & & $\mathrm{VL}$ & $\mathrm{L}$ \\
\hline
\end{tabular}


On the palm oil industry line, the excellence of the polyol industry looks at the main activities of logistics into, operations, and marketing and sales. These advantages have not at the maximum level, but only at the intermediate level. While other major activities are in the low (low) category.

Assessments with the same criteria and methods are done back to the poliol industry, but from a poly urethane industry standpoint. The assessment is done by different experts with the assessment from the perspective of the palm oil industry, tailored to its expertise. Assessment results are presented in table 4.

Table 4. Results of fuzzy linguistic label operations for assessment of the main activity of the industrial value chain of Poliol, from the perspective of the polyurethane industrial value chain (petrochemical)

\begin{tabular}{|c|c|c|c|c|c|c|c|c|}
\hline \multirow{2}{*}{$\begin{array}{c}\text { Main } \\
\text { Activities }\end{array}$} & \multirow[b]{2}{*}{ Main Activities Details } & \multicolumn{2}{|c|}{ Procurement } & \multirow{2}{*}{$\begin{array}{l}\text { Technology } \\
\text { Development }\end{array}$} & Infrastructure & \multirow{2}{*}{$\begin{array}{r}\text { Human Res } \\
\text { Development }\end{array}$} & Sustainability & \multirow{3}{*}{ Agregate } \\
\hline & & & & & & & & \\
\hline & & & $M$ & $\mathrm{M}$ & \begin{tabular}{|l|}
$\mathrm{L}$ \\
\end{tabular} & $\mathrm{VL}$ & $\mathrm{H}$ & \\
\hline & Material Supply & 1.2599 & $\mathrm{VL}$ & $2.2894 \mathrm{~L}$ & $1.5874 \mathrm{VL}$ & $1 \mathrm{VL}$ & $1 \mathrm{~L}$ & \\
\hline Internal & Warehousing & 3.3019 & $M$ & $3 \mathrm{M}$ & $1.2599 \mathrm{VL}$ & $1 \mathrm{VL}$ & $1.2599 \mathrm{~L}$ & \\
\hline \multirow{6}{*}{ Logistics } & Inventory Control & 3.6342 & $\mathrm{M}$ & $2.2894 \mathrm{~L}$ & \begin{tabular}{|l}
$1 \mathrm{VL}$ \\
\end{tabular} & $1 \mathrm{VL}$ & \begin{tabular}{|r|r|}
$1 \mathrm{~L}$ \\
\end{tabular} & \\
\hline & Purchase Transport & 2.6207 & L & $2 \mathrm{~L}$ & $1 \mathrm{VL}$ & $1 \mathrm{VL}$ & $1.2599 \mathrm{~L}$ & \\
\hline & Retur & & $\mathrm{M}$ & $2 L$ & $1 \mathrm{VL}$ & $1 \mathrm{VL}$ & $1.2599 \mathrm{VL}$ & \\
\hline & & & $\mathrm{M}$ & \begin{tabular}{l|l}
$L$ \\
\end{tabular} & \begin{tabular}{|l|l|}
$\mathrm{ML}$ \\
\end{tabular} & \begin{tabular}{l|l}
$\mathrm{VL}$ \\
\end{tabular} & \begin{tabular}{|l|l|}
$L$ \\
\end{tabular} & $\mathrm{M}$ \\
\hline & Good Manufact.Practices & 2.6207 & L & $3.3019 \mathrm{M}$ & $1.5874 \mathrm{VL}$ & $1.5874 \mathrm{VL}$ & $1 \mathrm{VL}$ & \\
\hline & Process Control & 2.6207 & L & $4.3089 \mathrm{H}$ & $2.2894 \mathrm{~L}$ & $1.2599 \mathrm{VL}$ & $1 \mathrm{VL}$ & \\
\hline Production & Quality Control & & $M$ & $3.9149 \mathrm{M}$ & $2.2894 \mathrm{~L}$ & $1.5874 \mathrm{VL}$ & $1.2599 \mathrm{VL}$ & \\
\hline \multirow[t]{5}{*}{ Operation } & Research \& Development & 1.2599 & $\mathrm{VL}$ & $2.2894 \mathrm{~L}$ & $1.5874 \mathrm{VL}$ & $1.2599 \mathrm{VL}$ & $1.2599 \mathrm{VL}$ & \\
\hline & Cost Control & 1.2599 & $\mathrm{VL}$ & $1 \mathrm{VL}$ & $1.5874 \mathrm{VL}$ & $\begin{array}{ll}\mathrm{VL} \\
\end{array}$ & $1 \mathrm{VL}$ & \\
\hline & & & L & $M$ & $\mathrm{VL}$ & $\mathrm{VL}$ & $\mathrm{VL}$ & $M$ \\
\hline & Product Warehousing & & $M$ & $2.2894 \mathrm{~L}$ & $1.2599 \mathrm{VL}$ & $1 \mathrm{VL}$ & $1 \mathrm{VL}$ & \\
\hline & Stuffing & 2.2894 & $\mathrm{~L}$ & $1.5874 \mathrm{VL}$ & $1.8171 \mathrm{VL}$ & $1 \mathrm{VL}$ & $1 \mathrm{VL}$ & \\
\hline External & Transportation & 2.2894 & L & $2 \mathrm{~L}$ & $1.5874 \mathrm{VL}$ & $1 \mathrm{VL}$ & $1 \mathrm{VL}$ & \\
\hline \multirow[t]{3}{*}{ Logistics } & Product Absoption & 2 & $L$ & $1 \mathrm{VL}$ & $1.2599 \mathrm{VL}$ & $1 \mathrm{VL}$ & $1 \mathrm{VL}$ & \\
\hline & & & L & L & $\mathrm{VL}$ & $\mathrm{VL}$ & $\mathrm{VL}$ & $\bar{L}$ \\
\hline & Promotion/Advetisment & & $\mathrm{VL}$ & $1.2599 \mathrm{VL}$ & $1 \mathrm{VL}$ & $1 \mathrm{VL}$ & $1 \mathrm{VL}$ & \\
\hline Sales and & Customer Care & & $\mathrm{VL}$ & $1.2599 \mathrm{VL}$ & $1 \mathrm{VL}$ & $1 \mathrm{VL}$ & $1 \mathrm{VL}$ & \\
\hline \multirow[t]{3}{*}{ Marketing } & Pricing policy & & $\mathrm{VL}$ & $1 \mathrm{VL}$ & $1 \mathrm{VL}$ & $1 \mathrm{VL}$ & $1 \mathrm{VL}$ & \\
\hline & Communication & & $\mathrm{VL}$ & $1 \mathrm{VL}$ & $1 \mathrm{VL}$ & $1 \mathrm{VL}$ & $1 \mathrm{VL}$ & \\
\hline & & & $\mathrm{VL}$ & $V L$ & $\mathrm{VL}$ & $\mathrm{VL}$ & $\mathrm{VL}$ & $\mathrm{VL}$ \\
\hline \multirow[t]{3}{*}{ Services } & Aftersales service & 1.2599 & $\mathrm{VL}$ & $1 \mathrm{VL}$ & $1 \mathrm{VL}$ & $1 \mathrm{VL}$ & $1 \mathrm{VL}$ & \\
\hline & Training/Technical Assist & & $\mathrm{VL}$ & $1 \mathrm{VL}$ & $1 \mathrm{VL}$ & $1 \mathrm{VL}$ & $1 \mathrm{VL}$ & \\
\hline & & & $\mathrm{ML}$ & $\mathrm{VL}$ & $\mathrm{VL}$ & $\mathrm{VL}$ & $\mathrm{VL}$ & $\mathrm{VL}$ \\
\hline
\end{tabular}

Results from the perspective of the polyurethane industry show almost the same results, i.e. strength on the main factor is in the logistics and operation, but also remain at the medium level. The other major factors in the category are low and very low.

The line to find a more definite relationship between the two value chain systems, the value chain of the palm oil industry with the value chain of polyurethane industry in the polyphant industry pathway, the linguistic label data returned in the form of valuation weights Perception. The reversal process is called defuzzification. The magnitude of the resulting weight is mapped to read the relationship between the two judging perceptions as Figure 7.

In Figure 7 It can be found that almost all of the perception towards the core support factor of the polyol industry value chain can be fulfilled with the minimum medium capability, either from the industry chain of palm oil and from the perspective of the polyurethane industry (Petrochemical). 


\section{CONCLUSION}

The polyol industry can be developed in the industrial tree branch of glycerol / glycerin in the large palm oil industry phon. As of today, companies in Indonesia that seek glycerin production are still underdeveloped. Glycerin is generally the most end product of the palm oil fractionation industry, after cooking oil, margarine, shortening, and soap. In addition, glycerin is also a by-product of fatty acid esterification during biodiesel production.

The development of glycerin into polyols is very possible, through a stage of production of the fatty alcohol group. The process of breaking the chain on glycerol is carried out to obtain polyols. The importance of polyol production is to provide a passive alternative to polyols in polyurethane production. Polyurethane is a polymer formed from the reaction of polyols with isocyanates. Polyurethane itself is a polymer with many forms of products that can be made, ranging from adhesives, foams, fillers, to food packaging materials. The demand for urethane products in the world has never receded.

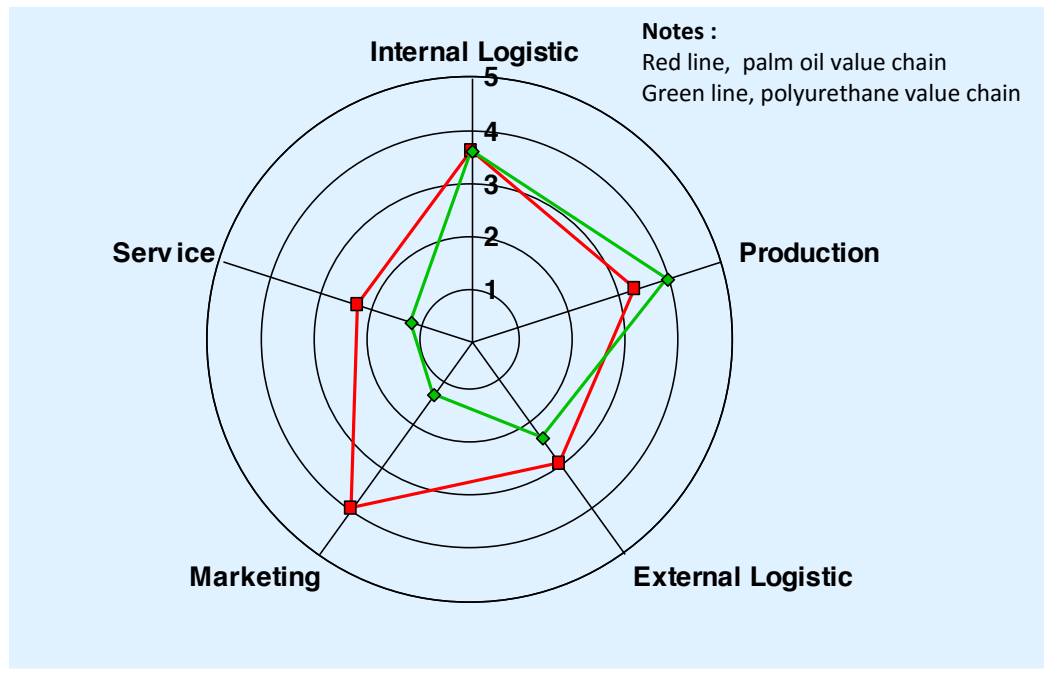

Fig. 7. The Association of the polyol industry value chain from the perspective of the oil palm industry's value chain with petrochemical polyurethane industry)

So far, polyols in urethane production have been supplied from petroleum processing, including the Polyol Polyether group. But along with the continued decline of petroleum production in the world, a number of researchers began directing the production of polyurethane using Polyol Polyester from vegetable oil. The specialty of polyurethane made from polyester polyols, it is more easily degraded so that it is more friendly to the environment.

The value chain analysis carried out in the palm oil industry chain shows that polyol production has added new pathways that can extend the palm oil downstream industry chain. Analysis carried out on the main chain and the combined oil palm industry chain has been successfully used to map the polyol industry value chain on the palm oil track. The extension of the palm oil industry value chain on the polyol industry pathway can unite the industry with the chain of production of the petrochemical industry, in this case polyurethane, which at least can help substitute raw materials.

A more detailed analysis of the perceptions of the role of the polyol industry in two directions, namely the palm oil industry chain with the polyurethane industry shows that there is 
a very large intersection of interests. Almost all perceptions of the role of key value chain activities in the polyurethane industry can be covered by the role of the value chain main activities in the palm oil polyol industry. Both value chains can be said to complement and complement each other. The production of polyester polyols can be absorbed by the needs of the polyurethane industry.

Research is also still trying to find stronger linkages between industries in the polyol chain. In addition to the supply chain and treacibility aspects, environmental factors will also be evaluated through several indicators. The linkage indicators between the chains enter the data analysis phase.

\section{REFERENCES}

Badri, K.H. 2012. Biobased Polyurethane from Palm Kernel Oil-Based Polyol. InTech. http://creativecommons.org/ licenses/by/3.0 diakses 16 Juli 2016.

Badri, K.H. dan M.S. Ngah. 2015. A Mini Scale Batch Reactor for the Production of Palm-Based Polyol. Sains Malaysiana 44(6) pp. 861-867

Bangga T.R. N.K. Agrawal, S.C. Sharma. 2002. Industrial Engineering and Management Science. Khanna Publishers. New Delhi.

Boustead, I. 2005. Eco-profiles of the European Plastics Industry : POLYOLS. PlasticsEurope, Brussels.

De Lavigne, C. 2015. Outlook for the Global Oleochemicals Industry. Frost \& Sullivan Pte Ltd, Singaphore.

Faleh, S.B. dan Zainal, A., 2001, "The Study of Conversion CPO to Polyol", Universitas Diponegoro, Semarang.

Gala, S. 2011. The Poliol Sinthesis from Sawit Oil with Epoksidasion and Hidroksilasion Reaction. Jurnal Chemica Vol. 12 Nomor 2 , pp. 36 - 43

Gapki. 2014. Industri Minyak Sawit Indonesia Menuju 100 Tahun NKRI : Membangun Kemandirian Ekonomi, Energi dan Pangan Secara Berkelanjutan. Gabungan Kelapa Sawit Indonesia, Jakarta.

Ionescu, M. 2005. Chemistry and Technology of Polyols for Polyurethanes. Rapra Technology Limited, Shawbury.

Kementerian Perindustrian RI. 2013. Kajian Teknis Industri Kelapa Sawit Berkelanjutan. Kemenperin RI, Jakarta

Kementerian Perindustrian RI. 2016. Cetak biru program nasional hilirisasi industri kelapa sawit, Kemenperin RI, Jakarta

Nang'ole, E., D. Mithöfer and S. Franzel. 2011. Review of guidelines and manuals for value chain analysis for agricultural and forest products. Published by the World Agroforestry Centre United Nations Avenue, Nairobi, Kenya

Neny dan Imron, 2004, "Pembuatan Polyol dari CPO dengan Reaksi Epoksidasi dan Hidroksilasi", Laporan Penelitian Jurusan Teknik Kimia FTI-ITS, Surabaya

Petrovic, Z.S. 2008. Polyurethanes from Vegetable Oils. Polymer Reviews 48: p. 109-155.

Rihayat, T., S. Salim , H. Agusnar, Fajri, dan Zaimahwati. 2015. Synthesis of polyurethane/clay nanocomposites based palm oil polyol coating. Journal of Mechanical Engineering and Sciences (JMES) ISSN (Print): 2289-4659; e-ISSN: 2231-8380; Volume 9, pp. 1580-1586 
Sharmin, E. dan F. Zafar. 2012. Polyurethane: An Introduction. InTech. http://creativecommons.org/licenses/by/3.0 diakses 16 Juli 2016.

Veenendaal, B. 2007. Renewable content in the manufacture of polyurethane polyols-An opportunity for natural oils. Polyurethane Magazine International 4(6): p. 352-359.

White, L. 2006. Renewable polyols gain ground as petrocheicals prices keep rising. Urethane Tehcnology, 23(4): pp. 22-30. 